\title{
PREPARING THE PRODUCTION OF A NEW PRODUCT IN SMALL AND MEDIUM-SIZED ENTERPRISES BY USING THE METHOD OF PROJECTS MANAGEMENT
}

\author{
Jolanta BIJAŃSKA, Krzysztof WODARSKI \\ Silesian University of Technology \\ Janusz WÓJCIK \\ Fabryka Drutu Gliwice Sp. z o.o.
}

\begin{abstract}
:
Efficient and effective preparation the production of new products is important requirement for a functioning and development of small and medium-sized enterprises. One of the methods, which support the fulfilment of this condition is project management. This publication presents the results of considerations, which are aimed at developing a project management model of preparation the production of a new product, adopted to specificity of small and medium-sized enterprises.
\end{abstract}

Key words: preparing the production of new product, projects management, small and medium enterprises

\section{INTRODUCTION}

Currently, among the important sources of growth and competitive advantage of small and medium-sized enterprises (SMEs) stands out their innovative activity and attainment through it proper performance of business. Such a view is presented by authors of many articles $[2,3,9,12]$. On the other hand, the results from the reports about the state of small and medium-sized enterprises, which are published by Polish Agency for Enterprises Development shows, that in recent years the innovative activity of SMEs is mainly focused on products and process innovations. In the first case important is to launch new product on the market, whose construction and technological features are significant different against the previous product. In the second case - it is important to introduce new or improved methods for improving the effectiveness and efficiency of the processes implemented in SMEs. Among these processes, it is important to emphasize the role of preparation the production of a new product, which is the area of the "battle for a product", which determines its future fate $[1,10]$. It follows that the SMEs, which want to succeed must pay great attention to the efficiency and effectiveness of preparation the production of a new product. Effectiveness should be assessed in relation to the customer's expectation, which are usually linked to the fulfilment by the product specific quality and technical requirements, as well as the preparation of its production in approved and possible shortest time. In turn, the effectiveness should be assessed in relation to the customer's and entrepreneur's expectation. The effectiveness for the customer mean that the approved budget can't be overspend, and for the entre- preneurs - cost-effectiveness of spending financial resources (for the preparation the production of product, its production and possible elimination of this production), which is estimate by proper criteria for evaluation of economic efficiency [4].

Focusing preparation the production of new product on the effectiveness and efficiency causes, that for its support, the methods oriented on time, quality, costs, economic efficiency and risk, should be use. One of them is project management. This method, from the beginning was combined with development of new products, and the definitions of project management often says, that it is undertaken in order to produce new, unique product $[11,14]$. However it should be noted that in the literature can be found a lot about project management, but none of them concerns the preparation the production of new product, and only a few of them refers to the development of products [14]. Moreover, presented in literatures considerations apply to large-sized enterprises, which have different specificity (quality characteristics) than SMEs, and it has impact for preparation the production of new product [7].

The objective of this article is to indicate possibility of the use of project management in the preparation the production of new product in SMEs, to support its effectiveness and efficiency. Mainly, the model of preparation the production of new product in SMEs, which is based on the approach used in project management, was presented. To develop them, it was necessary to make research in terms of preparation the production of new product and the conditions of the use of project management method in SMEs. 


\section{THE PROCESS OF PREPARATION THE PRODUCTION OF NEW PRODUCT IN A SMALL AND MEDIUM-SIZED ENTER- PRISE}

The existing literature, e.g. $[5,8,10]$ presents the considerations regarding preparation the production of new product in large enterprises, however lacks a reference to the SME sector. It is reasonable to say, that for the process of preparation the production, especially for its scope and participants, the quality characteristic related to the size of enterprise is important [7].

To determine the scope and participants, who are responsible for preparation the production of new product in SMEs conducted the study, which involved processing industrial enterprises, which are in Silesia region. Taking into account requirements of size of this article, only selected results were presented, which were important for development of a project management model of preparation the production of new product in SMEs.

The basis for the study was the survey, which concerned the activities scope and participants of the preparation the production of new product. It was assumed in this survey, that the preparation the production includes initial and proper phase, which are diverse in terms of actions and participants [4]. It was assumed, that the scope of the initial phase of preparation the production includes 11 actions, which are associated with the research work on the new construction and technology concepts. In the proper phase of preparation the production took into account the opportunity of implementation of 28 actions, which relates to structural and technology development of documentation, preparation of product prototype, its test production run and regular production. It was also assumed, that in the execution, control and approval of the results of highlighted stages may be involved 12 people and organizational units. In the survey it was possible to identify by the respondents, other actions and participants.

The survey was sent to 700 Silesian SMEs. In the results included answers from 173 proper filled in surveys, from which 127 was fill in by small-size enterprises, and 46 from medium-sized enterprises. The adopted the size of the statistical sample (173) was represented with the assumption: the size of the studied population of SMEs (20766), the confidence level $(0,95)$, the estimated size of fraction $(0,5)$, the maximum error $(0,05)$.

Selected by the respondents answers were characterized by a high degree of compliance. They show the preparation the production of a new product in small and medium-sized enterprises differ in the number of actions, as well as the number of participants.

In small-sized enterprises, respondents pointed out in total 11 actions of initial and proper phase of construction and technological preparation. In initial phase are: work out the concept of new product, study of license purchase, and order to prepare the product in line with customer requirements (indicated by respondents). In turn, in proper phase are: design of technological process, develop the technical and economical assumption (T\&EA), pre-production, check of pre-production, commissioning of pre-production, startup of mass production, design and technological supervising on start-up of mass production, end commissioning. In these actions are involved: owner, designer, technologist, production department, and customer.

In medium-sized enterprises, respondents pointed out 15 actions. In initial phase are: work out the concept of new product, study of license purchase, order to prepare the product in line with customer requirements or in line with owner's idea of this product (indicated by respondents). In proper phase are: develop the T\&EA design of technological process, prototype, test of prototype, commissioning the prototype, pre-production, test of pre-production, commissioning of pre-production, start-up of mass production, design and technological supervising on start-up of mass production, and end commissioning. In these actions are involved: owner, company management, chief designer, design department, chief technologist, technology department, production department, and customer.

Based on obtained results of these study, assumed the way of preparation the production of new product in SMEs [4], with 5 stages: develop the concept of new product, develop design and technology documentation, preparation of design and technological prototype (rarely prepared in small-sized enterprises), design and technological preparation of pre-production, and design and technological preparation of mass production.

\section{CONDITIONS FOR THE USE OF PROJECT MANAGEMENT METHODS IN SMALL AND MEDIUM-SIZED ENTERPRISES}

To show the conditions of use the project management method for the preparation the production of new product in SMEs, interviews and observations in 9 SMEs were done. These enterprises, during these interviews (point 1) declared to use the project management method for the preparation the production of new product and agreed to participate in further analysis.

The interviews were based on a questionnaire with a lower degree of standardization, which was developed taking into account the considerations, which were published in the literature [14]. The questionnaire included questions, which consider the conditions of use project management methods in the preparation the production of new product, which presented in 4 areas of project management:

1. Method and tools,

2. Human resources,

3. Design environment,

4. Project knowledge management.

The publication presents only the results, which are important for development of the project management method of production preparation.

According to the respondents, the conditions of use of project management method in SMEs:

1. In the area of method and tools is:

- based on the chosen project management methodology - preferable PRINCE2 (respondents indicated, that it would be useful to develop a model of preparation the production of new product, which is tailored to specify of SMEs, and based on PRINCE2 standards, because of the employees knowledge in this area),

- usage of documentation and methods for determining the business case of the project, time, cost and risk management,

- taking into account customer needs, for the formation of good relations and communication in the quality area requirements,

- the use of uniform distribution of the project at specific stages of preparation the production of new product. 
2. In the area of human resources are:

- determine the flow of information and documents between the project participants, including the moments of decision-making, in order of proper communications and collaboration between project participants and the customer,

- separation of roles and tasks for project participants.

3. In the area of project environment are:

- stakeholder management, e.g. suppliers, subcontractor.

4. In the area of knowledge management are:

- archiving documents, i.e. the knowledge about completed project, for its use in future projects.

\section{MODELS OF PREPARATION THE PRODUCTION OF NEW PRODUCT IN SMALL AND MEDIUM-SIZED ENTERPRISES, WITH THE USE OF PROJECT MANAGEMENT METHODS}

Due to differences in the way of preparation the production (point 1), a separate model for a small and for medium-sized enterprise was developed (Figure 1 and 2).

The main goal of developed these models is indication of the way of proceed in preparation the production in new product, targeted to meet the specific requirements of effectiveness and efficiency, by adopting an approach, which is used in project management, particularly in the PRINCE2 $[11,13]$. The essence of this approach is:

- adoption a uniform distribution of the implementation of preparing the production of new product, to the stages of project management,

- separation and define the tasks for the people which takes part in these stages, taking into account their knowledge, skills and experience,

- specify the way of motivating participants to engagement in preparation the production,

- indication, for the different stages of project management, way of working, techniques and documents, which usage affects the reduction of losses of budget, time schedule, and deterioration in business relationship with customers and stakeholders, as well as increase in profits, as a results of the proper use of resources.

The idea of the PRINCE2 methodology is based on 4 stages of project management: "Stage before project", "Stage of project start", "Stage of realization", "Last stage of realization". For each there are processes:

1. Preparation of project,

2. Strategic project management,

3. Project initiating,

4. Control of stages,

5. End stage management,

6. Product delivery management,

7. Project closure.

In developed models, pointed out phases (point 1), stages and actions of preparation the production, 4 stages of project management were indicated. For each stage, identified tasks for participants of preparation the production, which realization linked with bonus system. Moreover, way of working, technique and most important documents were shown. It was assumed, that the start of next stage must be preceded by a decision of approving the results. This will allow to gradual control of specific requirements of efficiency and effectiveness, and as the consequence its enable to quick detection of irregularities and minimize the risk of producing the product which is not in customer requirements, and inefficient spending of financial resources.

In models assumed, that the phase of pre-production, stage 1. - define concept of new product, is a "Stage before project", and the task, which are realized here, are in scope of preparation process of the project. The process starts when customer make order for preparation the production of new product, or start the study on the purchase of license, or submit the idea for a new product by the owner. Then, based on the results of the preliminary analysis of the technical feasibility and economic viability of preparation the production of new product, the task for designers is to develop the concept of new product, the description of which should be prepared as the document "Assumption for the project of preparing the production of a new product". This document is a preliminary of business case. Informations contained therein are the basis for the decision to start the project and preparation of "Project initiation document", which appoint the manager, project team (e.g. designer, technologies, production worker), and define their tasks.

Phase of proper preparation of production, stage 2 development of design and technological documentation, is a "Stage of project initiate". At this stage project manager, based on "Project initiation document " and „Project assumptions", should developed "Plan of stage of project initiation". It is a basis to manage the stage of project initiation, which includes the allocation of tasks in terms of T\&EA development, and design of technological process, and also monitoring the performance of assigned tasks and to help with solving the problems.

The stage of initiation is finishing the management process of final stage, in which the project manager collects, prepared by the project team, design and technological information (including technical documentation of product, functional and strength calculations, technical conditions, approval of quality and exploitation of product, the necessary tests of pre-production, the analysis of enterprise's production possibility to produce new product, establish the production size of new product, the scope of necessary investment, organizational changes and quality control. In addition, as a part of this process, the manager should prepare project plan, which include: realization schedule, budget, plan of risk, communication and stakeholders management - developed by using techniques of project management [11], and the result of evaluation of economical effectiveness of this the project [6]. Collective summary of design and technological information and plan of project in T\&EA is the basis of their approval in the course of the strategic management process.

Presented activities are characterized by strong statistical concentration, which is measurable with Gini index.

Selection of methodology made, based on information from interview and observation point 2.

Phase of proper preparation the production, stage 3 design and technological preparation of prototype (occur in medium-sized enterprises), as well as stage $4-$ design and technological preparation of mass production, which is the "Stage of realization". Its basis is process of control the phase, which include the development of "Plan of preparation the prototype" and then "Plan of preparation the preproduction", and monitoring their implementation in the area of research, execution and prototype and preproduction approval. 


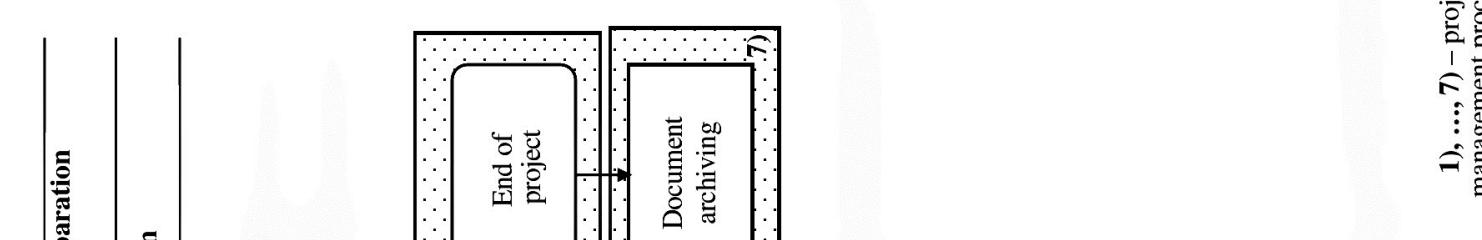

要营
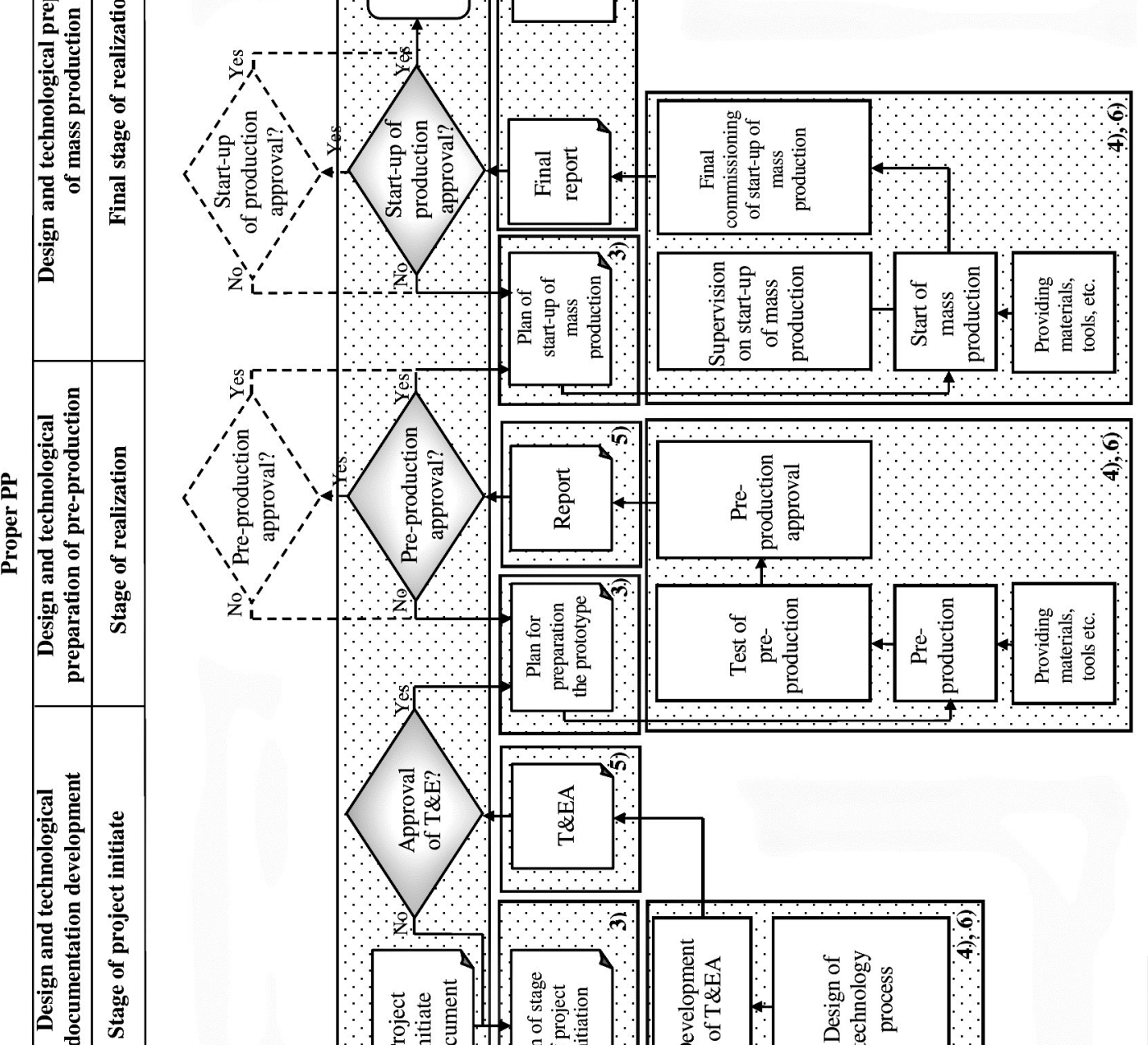

$\sum$ 望

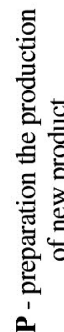

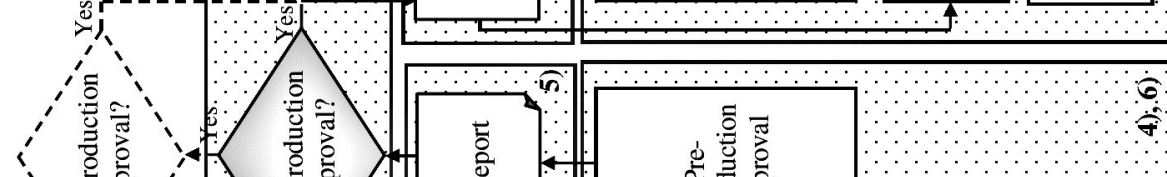

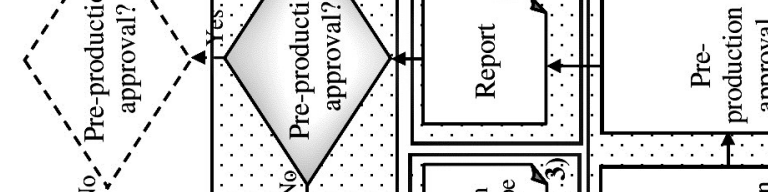
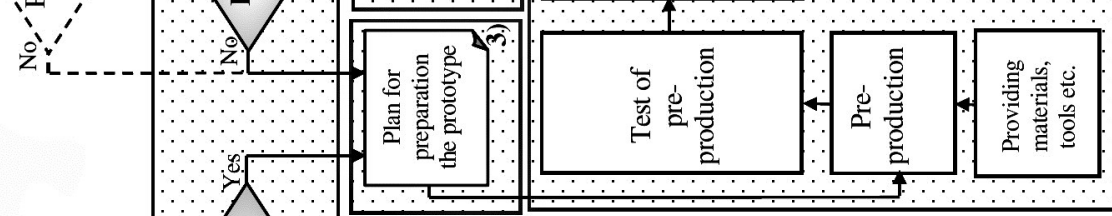

主

昰

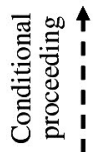

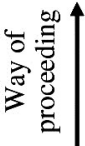
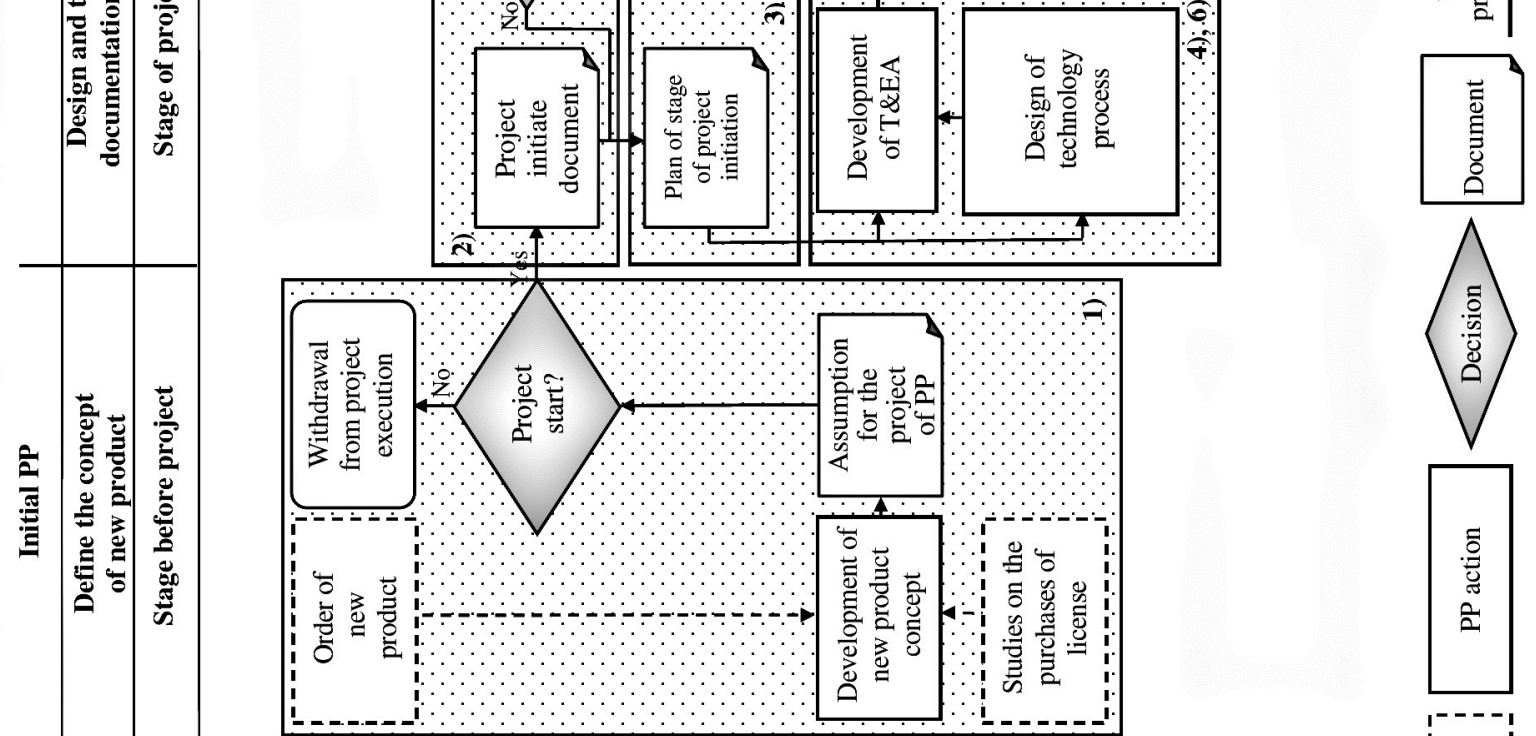

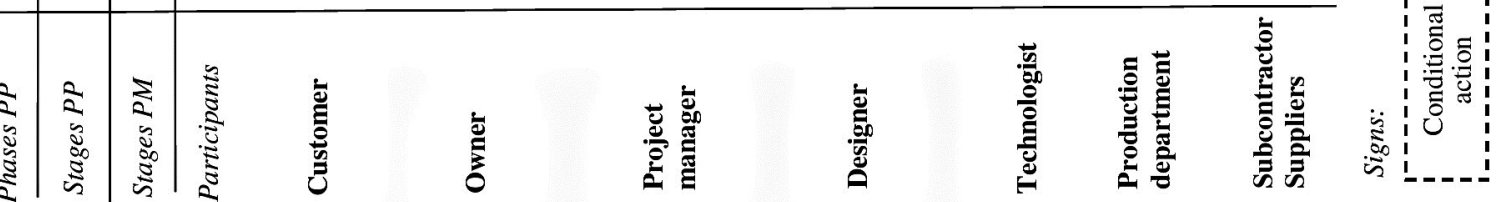




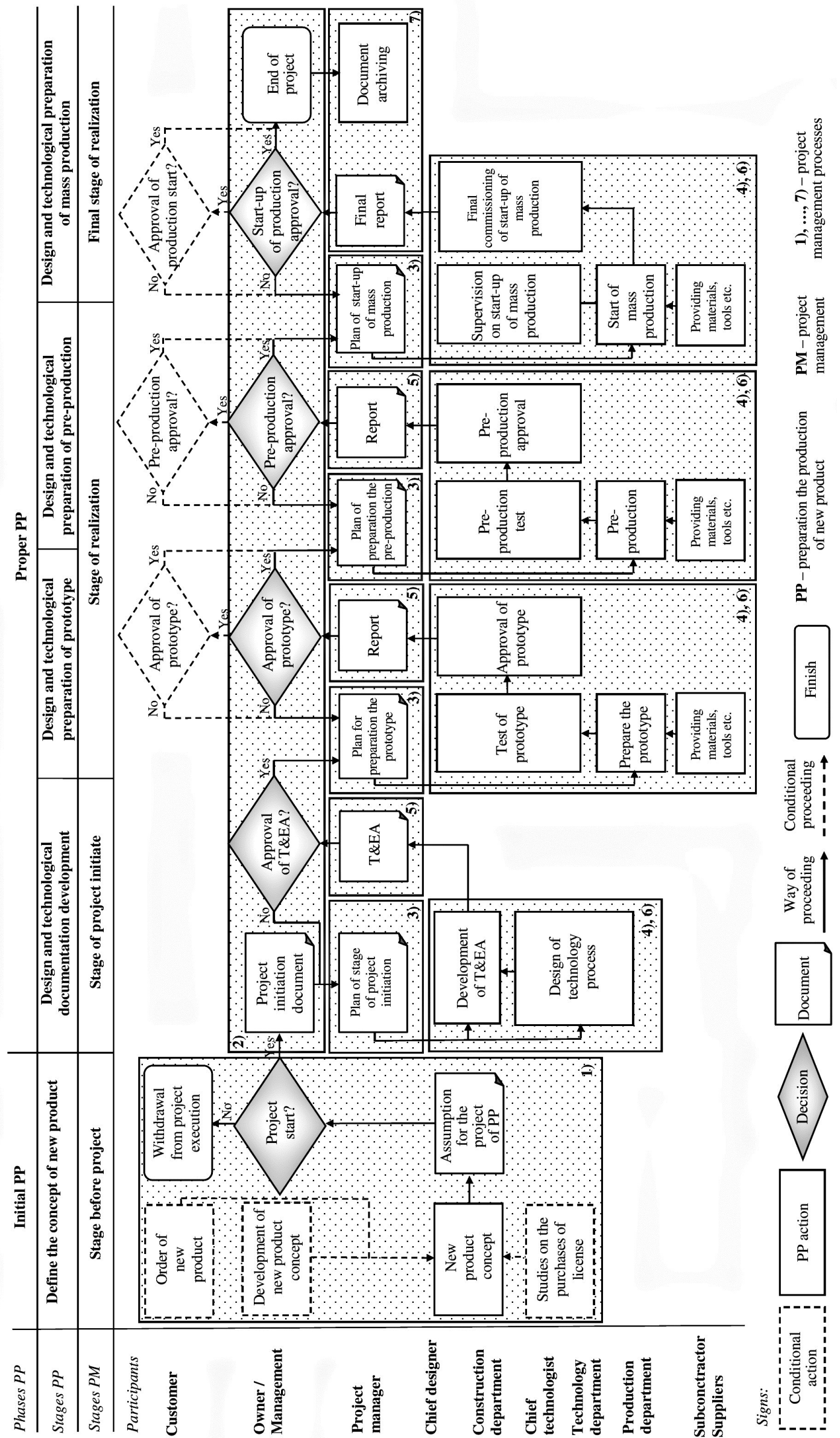


This process is carried out by the project manager, whose task is also the cooperation with subcontractors and suppliers - especially in the process of product delivery. There are two types of products.

The first, the product, which should be deliver for preparing the prototype and pre-production (test series), e.g. semi-finished product, materials, tools. The second - the results of actions in this stages, e.g. prototype, preproduction, or the reports of their implementation. During the approval of the prototype or pre-production customer can be present (optional and only if the preparation the production is because of customer order).

At this stage important is process of final stage management, in which project manager develop "Report of prototype implementation" and/or "Report of pre-production”.

Phase of proper preparation the production, stage 5. design and technological preparation of mass production, is the "Final stage of realizing". Similar to previous stage, its basis are processes of stage control and delivery of production which are necessary for mass production, which is the final product of this stage. The approval of start-up of mass production, customer can be present (if the preparation the production is because of customer order). Important process of this stage is finish of the project, where the essence is development of "Preparation of mass production report". Its approval allows to finish the project.

The results of process of each stage management, in particular ZTE, plans of each stage implementation, reports of finishing each stage and whole project, as well as rest of documents, should be archived for eventual usage in different projects.

\section{CONCLUSIONS}

Presented models were used in chosen SMEs for project management of preparation the production of new product. Based on, finished with success, 5 projects, it can be stated, that usage of these models:

1. Increase the effectiveness in achieving the objectives of the project of preparation the production of new product, which refer to:

- satisfaction of company owner, as a result of good project run and economic efficiency of this project, as well risk reduction,

- satisfaction of employees, as a result of precise scope and time schedule of realization the tasks and its link with bonus system,

- satisfaction of suppliers and subcontractors, as a result of good cooperation,

- customer satisfaction, as a result of fulfillment the quality and technical requirements, product delivery in approved, possible shortest time, and good communication,

2. Allows to shortening time by half, of preparation the production of new product, with respect to normal time for similar projects.

3. Contributed to rational usage of human resources, materials and financial resources, as a result of precise definition of needed people, machines, materials and budget.

4. Reduce the risk, due to adoption and execution of action which prevent its occurrence.
It should be emphasized, that presented models are just a proposition, although they are developed based on surveys in the scope of preparation the production of new product in SMEs.

In some SMEs, the preparation the production, may not include all the specified stages or actions, or may implement them other people or organizational department than were indicated. For example, in small-sized enterprises, some of participants of preparing the production, may have few functions (e.g. owner may be also a designer at the same time). Lack of some stages and actions, or other positions or organizational departments doesn't mean that developed models are not useful. It should be marked that, the aim of this development, was not mapping the most common, in SMEs, actions of preparation the production, and the people and organizational departments, responsible for implementing them. The essence of these models is the use of the approach used in project management, in particular in the PRINCE2 methodology, which supports the specific requirements of effectiveness and efficiency of preparation the production. Taking this into account, among the recommendations, which concern the use of the models, should be underline the need to adopt them to the specific enterprise, including its organizational structure, the specifics of the preparation the production and products, and as well the employees qualifications. It is important, to remove useless solutions for the enterprises, and to focus on the opportunities, which gives project management method.

\section{REFERENCES}

[1] E. Pająk, M. Klimkiewicz and A. Kosieradzka. Zarzq̨dzanie produkcjq i usługami, Warszawa: Polskie Wydawnictwo Ekonomiczne, 2014, p. 94.

[2] E. Skawińska. Konkurencyjność przedsiębiorstw - nowe podejście, Warszawa-Poznań: Wydawnictwo Naukowe PWN, 2002, p. 83.

[3] G. Hamel and C.K. Prahalad. Przewaga konkurencyjna jutra, Warszawa: Business Press, 1999, p. 14.

[4] J. Bijańska, K. Wodarski and J. Wójcik. „Decyzje w przygotowaniu produkcji nowego wyrobu w małych i w średnich przedsiębiorstwach", in Zeszyty Naukowe Politechniki Ślq̨skiej (s. Organizacja i Zarządzanie), Gliwice, 2016.

[5] J. Lewandowski, B. Skołud and D. Plinta. Organizacja systemów produkcyjnych. Warszawa: Polskie Wydawnictwo Ekonomiczne, 2014.

[6] J. Wójcik, J. Bijańska and K. Wodarski. „Economic aspects of preparing the production of a new product", in Management Systems in Production Engineering, vol. 4(20), October 2015.

[7] J. Wójcik. „Wybrane problemy w przygotowaniu produkcji nowego wyrobu w małych i średnich przedsiębiorstwach" in Zeszyty Naukowe Politechniki Ślqqskiej (s. Organizacja i Zarządzanie), z. 83, Gliwice, 2015.

[8] J. Matuszek. Inżynieria produkcji, Bielsko Biała: Wydawnictwo Politechniki Łódzkiej, 2000.

[9] K. Poznańska. „Czynniki sukcesu małych przedsiębiorstw w Polsce", in Ekonomika i Organizacja Przedsiębiorstwa, vol. 5, May 2006, p. 91.

[10] K. Szatkowski. Przygotowanie produkcji, Warszawa: Wydawnictwo Naukowe PWN, 2008. 
[11] M. Wirkus, H. Roszkowski, E. Dostatni and W. Gierulski. Zarzqdzanie projektem, Warszawa: Polskie Wydawnictwo Ekonomiczne, 2014.

[12] M.E. Porter. Porter o konkurencyjności, Warszawa: Polskie Wydawnictwo Ekonomiczne, 2001, p. 192.
[13] PRINCE2TM - Skuteczne Zarządzanie Projektami, 2nd ed. (Polish), Londyn: Crown Copyright, 2010.

[14] S. Spałek. Dojrzałość przedsiębiorstwa w zarzqdzaniu projektami, Gliwice: Wydawnictwo Politechniki Śląskiej, 2013.

dr inż. Jolanta Bijańska,

dr hab. inż., Krzysztof Wodarski, prof. nzw. w Pol. śl.

Silesian University of Technology,

Faculty of Organization and Management

ul. Roosevelta 26, 41-00 Zabrze, POLAND

e-mail: jbijanska@polsı.pl,

krzysztof.wodarski@polsı.pl

dr inż. Janusz Wójcik

Fabryka Drutu Gliwice Sp. z o.o.

ul. Dubois 45C, 44-100 Gliwice, POLAND

e-mail: j.wojcik@fdg.com.pl 